\title{
Pluralização da representação política e legitimidade democrática: lições das instituições participativas no Brasil
}

\author{
\begin{tabular}{c}
\hline \hline $\begin{array}{c}\text { Debora Rezende de Almeida } \\
\text { Instituto de Ciência Política } \\
\text { Universidade de Brasília }\end{array}$ \\
\hline \hline
\end{tabular}
}

Resumo: A redemocratização brasileira alterou profundamente as relações entre Estado e sociedade e o casamento entre representação e democracia. As mudanças não ficaram restritas à representação eleitoral e estatal, mas atingiram a esfera de atuação da sociedade civil. A incorporação direta dos cidadãos no processo decisório é uma das mais significativas inovações na democratização do Brasil. Este artigo defende que a nova arquitetura institucional que amplia os canais de conexão entre Estado e sociedade inaugura um novo momento da representação política no país. Atores sociais representam em conjunto com agentes governamentais interesses da sociedade em relação a determinado tipo de política pública, mas sem se tornar Estado, e, vice. versa. Para compreensão dos potenciais democratizantes dessas transformações, este artigo propõe, baseado no debate internacional, uma releitura do conceito de representação política, bem como dos seus critérios de legitimidade, a saber, accountability e responsividade. Em seguida, destaca as especificidades da representação nas instituições participativas brasileiras. Argumenta que sua inserção institucional e interseção com arenas estatais e societais são características que impactam o exercício da accountability e da responsividade.

Palavras-chave: representação; democracia; legitimidade; instituições participativas

\begin{abstract}
Brazilian redemocratization has profoundly transformed the relations between State and society and the marriage between democracy and representation. The changes were not restricted to electoral and state representation, but reached civil society's spheres of action. The direct incorporation of citizens into policymaking processes is one of the most significant innovations of democratization in Brazil. This article argues that the new institutional architecture that expands the connections between State and society inaugurates a new moment of political representation in the country. Here, social actors represent along with government agents the interests of society in relation to certain types of public policy, without being incorporated by the state, and vice versa. In order to understand the democratizing potentials of these transformations, this paper proposes, based on international debates, a reinterpretation of the concept of political representation, as well as its criteria of legitimacy, namely, accountability and responsiveness. In addition, the paper highlights the specificities of representation in Brazilian participatory institutions. It argues that its institutional placement and intersection with state and societal arenas are characteristics that influence the practice of accountability and responsiveness.
\end{abstract}

Keywords: representation; democracy; legitimacy; participatory institutions 
ALMEIDA, D. R. Pluralização da representação política e legitimidade democrática... Introdução

A transição democrática brasileira, que se inicia no regime militar e se consolida com a Constituição de 1988, alterou profundamente a dinâmica das relações entre Estado e sociedade. Um dos campos visíveis destas transformações é o casamento entre representação e democracia. É possível afirmar que em nenhum momento a representação democrática, fundada em um sistema de checks and balances e delegação universal da soberania dos indivíduos, foi constituinte das relações entre Estado e sociedade no país ou teve primazia sobre as demais formas de se pensar e estruturar a representação. Tampouco surgiram alternativas capazes de contestar o exercício da representação restrito à esfera estatal e de repensar a dualidade Estado e sociedade. O cenário político pós-88 é completamente diverso. A democracia deixa de ser uma ideia subjacente para se tornar a ideia-força organizadora da representação. Nesse processo, o sistema político passou por um movimento intenso de inovação institucional marcado pela pluralização do sistema partidário; democratização do sistema eleitoral; reorganização político-administrativa do país; ampliação das responsabilidades do Estado no provimento de direitos sociais e criação de canais variados de interação Estado/sociedade e de expressão da soberania popular. Como se pode perceber, as mudanças não ficaram restritas à dimensão eleitoral e estatal da representação, mas atingiram a esfera de atuação da sociedade civil. A consolidação do sufrágio universal, como meio de influência do cidadão na esfera pública, veio acompanhada de formas descentradas de manifestação da pluralidade, as quais situam as eleições como apenas um dos momentos de julgamento político (URBINATI, 2006a).

Nos últimos anos, as abordagens teóricas sobre as manifestações da sociedade civil e sua interação com o Estado destacaram as dimensões participativas e deliberativas desses encontros. Recentemente, ganha força a preocupação com o papel representativo da sociedade civil, não obstante a ausência de mecanismos eleitorais. A constatação de que os atores sociais agem e falam em nome de públicos, temas ou grupos não presentes demanda uma noção ampla de representação para além do quadro teórico consolidado da representação eleitoral. Alguns esforços vêm sendo feitos no sentido de avaliar a legitimidade dessa representação e sua contribuição para a qualidade da democracia (AVRITZER, 2007; Lavalle, Houtzager, Castello, 2006a; 2006b; Lüchmann, 2011; Abers e KeCK, 2008a; 2008b; LAVALLE E ISUNZA VeRA, 2011). Contudo, falta uma análise sistemática sobre como distintos desenhos representativos respondem aos desafios da representação e uma atenção às diferenças entre o contexto nacional e internacional.

O objetivo central deste artigo é avaliar em que medida a representação da sociedade civil transforma o modo de pensar e praticar a representação no que tange aos atores que representam e como representam. Em suma, como estas experiências respondem ao desafio de democratizar a representação e quais são os critérios para se avaliar a sua legitimidade? Um dos pressupostos defendidos neste artigo é que a experiência brasileira traz questões inovadoras para a reformulação do conceito de representação, uma vez que alguns mecanismos de interação da sociedade civil extrapolam a influência informal, teorizada pela literatura internacional (CASTIGLIONE E WARREN, 2006; SAWARD, 2006; 2011; DRYZEK, 2001). A diversificação de atores e espaços políticos tem um sentido específico no país, visto que as inovações da sociedade civil foram canalizadas para dentro do sistema político. Desde a Constituição de 1988, uma diversidade de instituições que conectam Estado e sociedade no processo de formulação e fiscalização de políticas públicas foi instituída nas diferentes áreas de políticas e níveis da 


\section{OPINIÃO PÚBLICA, Campinas, vol. 20, no 1, abril, 2014, p. 96-117}

Federação. Sendo assim, argumento que é preciso trazer para o centro do debate duas características que influenciam no processo de accountability e responsividade nas instituições participativas (IPs): sua inserção institucional e a interseção com as esferas estatal e societal.

Tal investigação divide-se em três seções. A primeira apresenta o contexto de mudança da representação política e as principais transformações institucionais na relação entre Estado e sociedade no período da redemocratização e uma proposta de compreensão das instituições participativas no contexto da representação política. A segunda seção propõe uma redefinição do conceito e dos critérios de avaliação da legitimidade democrática da representação, baseada na leitura crítica de intérpretes recentes da teoria política. A terceira seção entra no universo das IPs, apontando o que mudam em relação ao exercício da representação, tendo como norte os debates internacional e brasileiro sobre a pluralização da representação. Propõe discutir os impactos da inserção institucional, no que tange ao poder exercido pelas IPs e às especificidades do processo de autorização. Por fim, discute como a interseção e a consequente interação das IPs com as arenas societal e estatal influenciam no exercício da accountability e responsividade. A interação é considerada a partir de 3 direções: com os atores governamentais, as organizações sociais e os cidadãos.

\section{Brasil democrático: mudanças na esfera política e social}

A renovação na forma de pensar e praticar a representação é um marco do período democrático recente, tanto da perspectiva da democracia eleitoral, como da relação entre Estado e sociedade. Os sinais dessa transformação começam a ser sentidos no final do período militar, com a intensificação das mobilizações por parte da sociedade e a crescente oposição ao regime, a partir das eleições de 19741 . No que se refere à esfera pública, Avritzer (2009, p. 26) salienta que a redemocratização brasileira, no período entre 1974 e 1988, foi marcada não apenas pelo restabelecimento da competição política, mas também pelo aumento na propensão de criação de formas de associações voluntárias e independentes. A diferença foi expressa também qualitativamente, com o surgimento de um associativismo ligado a demandas materiais e não materiais - organizações de bairro, de proteção ambiental, de direitos humanos e de questões étnicas -, inexpressivas em períodos precedentes. O conceito de sociedade civil, nesta época, foi definitivamente introduzido no vocabulário político e associado à ideia de mobilização contra o regime militar, para alterar o status quo no plano estatal e lutar por um regime democrático que visasse políticas públicas que atendessem a grande maioria da população.

A redemocratização levou a uma série de mudanças nas esferas política e societal responsáveis por alterar a forma de vinculação entre Estado e sociedade no Brasil. Entre elas destaco três direções do ponto de vista da representação. A primeira está relacionada às questões centrais da representação liberal. Há o fortalecimento da democracia eleitoral e das instituições tradicionais de representação . pluralização dos partidos políticos; surgimento do primeiro partido de massas, o Partido dos Trabalhadores (PT), e organização dos três Poderes (KECK, 1992; AVRITZER, 2009). A aceitação da legitimidade que tem origem no consentimento dos cidadãos é um marco do período. A segunda e terceira referem-se a espaços de expressão e representação da sociedade. Uma voltada para o pluralismo de grupos, como sindicatos e organizações de trabalhadores e patrões, que passaram a

\footnotetext{
${ }^{1}$ Em 1974, a oposição (MDB - Movimento Democrático Brasileiro) sai vitoriosa nas eleições majoritárias em 16 estados, elege 16
} dos 22 senadores e 160 dos 364 deputados. 
ALMEIDA, D. R. Pluralização da representação política e legitimidade democrática...

apresentar como tendência traços de autenticidade e consistência sem contrapartida na anterior tradição "peleguista" (REIS, 1980)2. Outra organizada fora da órbita da competição de grupos e interesses, a qual introduz a pluralidade nas formas de relação entre Estado e sociedade, a partir de arranjos formais e institucionalizados e também de experiências informais.

Essa terceira mudança desloca a representação política do campo exclusivo da esfera eleitoral e do pluralismo de grupos com recursos de poder e de organização. Diante do déficit democrático e de accountability, após anos de ditadura militar e cerceamento das liberdades civis e políticas, uma das apostas para democratização do Estado brasileiro era a necessidade de um enraizamento social por meio de arenas de negociação com a sociedade civil. Desse modo, o período democrático inaugura um momento na história do país em que os componentes elitista e autoritário perdem centralidade.

A participação social no processo decisório de políticas públicas e como princípio de organização da República brasileira consubstanciou-se com a Constituição de 1988, a qual declara em seu artigo primeiro, parágrafo único, que todo o poder emana do povo, que o exerce por meio de representantes eleitos ou diretamente. As práticas participativas/representativas vão desde as mais tradicionais, como o referendo e o plebiscito, até as menos conhecidas, como as conferências de políticas públicas, passando pela reestruturação e ampliação de experiências preexistentes, como as audiências públicas, os conselhos e os comitês de bacia hidrográfica, sem prescindir da valorização de práticas menos afamadas, como as ouvidorias e as mesas de negociação e de diálogo, e da criação de espaços completamente distintos, como os orçamentos participativos. A participação, desse modo, cobre repertório amplo de influência direta dos cidadãos, como se dá nos referendos, plebiscitos e iniciativa popular, e formas de participação indireta e via representação, por exemplo, nas instituições participativas (IPs), que introduzem novos pontos de interação constante com o Estado. De acordo com definição de Avritzer (2009, p. 8), essas são instituições que operam simultaneamente por meio dos princípios de participação e representação; transformam características voluntárias da sociedade civil em formas de permanente organização política; interagem com partidos políticos e atores estatais e para as quais o desenho institucional tem grande relevância na sua efetividade.

A composição é variada, incluindo desde cidadãos voluntários até indivíduos membros de organizações sociais (ONGs, associações de moradores, sindicatos, organizações trabalhistas, entidades filantrópicas, etc.) e movimentos sociais. A classificação proposta por Avritzer (2009, p. 69.74) distingue entre desenhos mais abertos em termos da inclusão de todos os cidadãos, nos quais o governo tem um papel de facilitador do processo deliberativo, como os orçamentos participativos (bottom-up design); passando por desenhos de compartilhamento de poder - conselhos de políticas - (power-sharing design), cuja participação se dá em grande maioria por membros de organizações da sociedade civil eleitos ou indicados pelas mesmas e que compartilham poder de decisão com o governo; até desenhos de ratificação - planos diretores participativos - (ratification design), nos quais participantes de associações representativas podem aprovar ou rejeitar propostas do Estado, mas não têm poder de proposição.

O cenário pós-88 é marcado por uma ampla gama de esferas públicas possíveis em que a cidadania pode ser exercida e os interesses da sociedade não somente representados, mas também fundamentalmente re/modelados (ALVAREZ, DAGNINO, ESCOBAR, 2000). É importante lembrar que, para

\footnotetext{
2 Importante destacar que as análises sobre a representação de interesses divergem sobre a possibilidade de "independência"
} em relação aos aparelhos do Estado e o surgimento de um corporativismo de cunho mais pluralista (DAGNINO, 2004). 


\section{OPINIÃO PÚBLICA, Campinas, vol. 20, no 1, abril, 2014, p. 96-117}

além das IPs e grupos de interesse, o Estado mantém formas de legitimação com a sociedade, seja pelo controle direto exercido por meio de protestos e pressão da sociedade, seja pelo estabelecimento de parcerias na prestação de serviços com ONGs e organizações sociais. Neste artigo, as mudanças no modo de pensar e praticar a representação serão discutidas considerando o debate internacional sobre pluralização da representação e as experiências brasileiras, especialmente das IPs. Tais instituições introduzem uma alteração significativa na concepção de representação, pois o foco não está no número de vezes que o cidadão participa, mas na forma como participa e em nome de que e de quem participa (PINTO, 2004). Além do número de vezes que o cidadão é chamado a escolher o seu representante, existe abertura política para sua manifestação na esfera pública e nas instituições que o conectam com a esfera política. A inclusão social é diferente do modelo autoritário e corporativo, no qual a sociedade em geral participava apenas por meio de canais abertos e sob regulação do Estado ou dentro de um escopo delimitado de interesses. O Estado continuou como indutor da participação em alguns canais, como orçamentos participativos, conselhos e planos diretores, mas a sociedade tem um papel relevante na formatação desses espaços, ao transferir práticas sociais e culturais para o nível institucional e pluralizar as áreas e temáticas sob sua influência (AVRITZER, 2009).

A interação frequente e institucionalizada entre atores governamentais e não-governamentais muda a forma de pensar e praticar a representação no país, no que tange aos atores que representam. Embora não tenham sido eleitos diretamente pela comunidade receptora da política pública, conselheiros, membros de comitês de bacia hidrográfica e delegados de conferências nacionais são responsáveis por definir padrões de atendimento, propor mudanças na formulação da política e fiscalizar sua implementação. Meu argumento é que a introdução de instituições participativas no Brasil inaugura um novo momento de relação entre Estado e sociedade ${ }^{3}$, responsável por borrar ou ofuscar a separação moderna entre esfera política e social. Atores sociais representam, em conjunto com agentes governamentais, interesses da sociedade em relação a determinado tipo de política pública, mas sem se tornar Estado, e, vice-versa, os atores governamentais não se tornam sociedade. Além disso, a indefinição destas fronteiras dá.se no momento em que atores estatais e líderes comunitários ocupam espaço dentro de instituições estatais, assim como dentro de redes da sociedade civil (KECK, 2003; WAMPLER, 2010). O período iniciado na década de 1980 inaugura um novo ciclo, no qual os polos Estado e sociedade não são vistos como antagônicos, mas complementares. As implicações dessa interação para a legitimidade da representação serão discutidas na terceira seção.

A ideia de que atores sociais por vezes se apresentam não apenas como defensores de demandas individuais, mas sim coletivas, demanda a redefinição do conceito de representação legítima e democrática. Os critérios de avaliação não são os mesmos da teoria clássica de representação, sendo necessário construir novas estratégias metodológicas para o seu estudo. A próxima seção se ocupa desse desafio, a partir de um balanço crítico da literatura internacional.

\footnotetext{
3 De acordo com Vianna (1999), a "evolução" da representação política moderna pode ser vista a partir de 3 momentos: separação entre Estado e sociedade visível na rota liberal contratualista que separa as soberanias públicas e privadas; generalização do privado no público via sufrágio universal e, finalmente, publicização do privado, por meio da intervenção direta na economia e nas políticas sociais. Apesar de não ter seguido esta rota, é possível vislumbrar estes momentos na história política do Brasil. Atualmente, o privado ou social encontra outras maneiras de generalização, seja por meio de mecanismos de pressão da sociedade, seja pelo controle direto de políticas públicas e do representante, o que nos colocaria no quarto momento de representação política no país, conforme Almeida (2011).
} 


\section{ALMEIDA, D. R. Pluralização da representação política e legitimidade democrática...}

\section{Quando o representado se torna representante}

Nádia Urbinati (2006a; 2006b; 2011) é uma das autoras atuais de destaque na redefinição do conceito de representação, que desde o trabalho de Pitkin (1967) e de Manin (1997) não ganhava notoriedade na teoria política. Apesar de amplamente discutida na literatura, a representação política ficou reservada às tendências pluralistas e institucionalistas que reduziram o debate ao tema do governo representativo e à lógica da representação do Estado (ARAujo, 2009; KNIGHTS, 2009; LAVAlle e Araujo, 2008; VIEIRA E RUNCIMAN, 2008). Ao reconectar a representação com a ideia de soberania, a partir de uma revisão crítica da obra de Rousseau, a autora abre espaço para outras formas de representação democrática. Em termos resumidos, ela mostra que a visão da soberania como um ato unitário da vontade e, consequentemente, da representação como um ato de transferência da soberania, responde pela inviabilidade da representação no contratualista. Rousseau defende uma democracia delegada e não representativa a partir de um modelo contratual e privado de alienação de direitos e não de um modelo público. A saída para a reabilitação da representação como fundamento da democracia, proposta por Urbinati (2011, p. 26), é a reinterpretação do conceito clássico de soberania popular como uma diarquia que envolve vontade e julgamento político ${ }^{4}$. A eleição, desse modo, não é um ato de transferência da soberania, mas um dos momentos da relação entre representante e representado. Diante da natureza dual da representação, de um lado, transmite a ideia de agir no lugar do outro como agente autorizado, de outro, a noção de que é um processo de criação de uma unidade que não existia antes, a autora argumenta igualmente pela dualidade de suas características, uma ativa e outra passiva. A representação é dependente tanto da vontade que autoriza o representante a agir em nome de alguém, quanto do julgamento político ou monitoramento do representado ${ }^{5}$ para dar vida a esta criação.

Nessa perspectiva, a representação deixa de ser sinônimo de democracia eleitoral, recuperando a dimensão deliberativa, apresentada por Stuart Mill', e a relação de interdependência entre representante e representado. "Em uma palavra, a representação pode incentivar a participação política na medida em que seu caráter deliberativo e sua característica de julgamento expandem a política para além dos estreitos limites da decisão e do voto" (URBINATI, 2006a, p. 16, tradução da autora). 0 dualismo entre Estado e sociedade é superado, conforme o primeiro precisa ser constantemente recriado e dinamicamente ligado à sociedade a fim de passar leis. Para a autora, as múltiplas fontes de informação, comunicação e influência que cidadãos ativam por meio da mídia, movimentos sociais e partidos políticos, não são acessórios, mas constitutivos da representação política. A soberania popular,

\footnotetext{
${ }^{4}$ Para Avritzer (2007), a autora propõe uma substituição do conceito de soberania popular pelo de julgamento político, e não uma reinterpretação. Apesar da diarquia estar mais clara no artigo de 2011 , considero que essa ideia já está presente no livro de 2006a. Nesse trabalho, Urbinati enfatiza que é necessário trazer a ideia de soberania para dentro do domínio do julgamento e opinião. Ou seja, esses são fatores da soberania, não seus substitutos (Ibid., p. 106). Outro ponto de difícil compreensão na autora se refere à conciliação entre vontade e julgamento político. Urbinati parece indicar que a vontade soberana se expressa em momentos eleitorais intermitentes (a vontade soberana está ligada ao ato de autorização e à presença direta e com autoridade para tomar decisões) e o julgamento político, que também constitui fator da soberania, se expressa na contínua influência e poder dos cidadãos em relação às instituições representativas - sua presença indireta, informal e não authoritative (URBINATI, 2011, p. 25.26).

${ }^{5}$ Aqui Urbinati está claramente indo de encontro à tese hobbesiana, segundo a qual a representação, por ser um ato de criação de uma unidade que não existe antes do pacto, não tem compromisso com a vontade dos indivíduos. Para Hobbes, é a unidade do representante não a do representado que torna a pessoa una. Tendo em vista que a representação não é um ato de retratar um corpo unificado previamente, ela pode ser realizada por um corpo individual com uma característica representativa. Ao contrário dos autores parlamentares que defendiam que a representação deve se dar à imagem e semelhança da população, Hobbes sustenta um poder absoluto, no qual o representante age por si mesmo (SKINNER, 2005, p. 173).

${ }^{6}$ Para Stuart Mill, o Parlamento é o espaço da diversidade e complexidade da sociedade. A representação do bem comum e do público poderia emergir da assembleia representativa, por meio da deliberação e manutenção do julgamento por seus constituintes (URBINATI, 2006a).
} 


\section{OPINIÃO PÚBLICA, Campinas, vol. 20, no 1, abril, 2014, p. 96-117}

nessa interpretação, é fonte de tensão endógena entre o poder institucionalizado do Estado e extrainstitucionalizado da sociedade. A democracia representativa começa com eleições, mas se desenvolve para além delas, incluindo tanto a participação quanto a representação não eleitoral exercida por atores sociais. A diferença dessa última em relação à representação eleitoral diz respeito à ausência de um poder com autoridade "authoritative power", embora tenha o poder de influenciar a direção política de um país (URBINATI, 2011).

Urbinati contribui para apresentar uma teoria da representação democrática que não está confinada ao governo representativo ou suas instituições tradicionais, englobando a representação não eleitoral da sociedade civil, principalmente no artigo de 2011, como expressão do julgamento político. A sociedade civil, porém, mantém um poder negativo de influenciar, investigar e censurar. Duas questões, entretanto, permanecem sem resposta. Primeiro, se existe algum critério para avaliar a legitimidade dos julgamentos políticos ou opiniões emanadas da sociedade em nome de uma coletividade. Segundo, não se sabe como interpretar o poder com autoridade (authoritative power) da sociedade civil nas estruturas do Estado brasileiro, na ausência da vontade expressa pelos indivíduos para que outros ajam em seu nome.

Tendo em vista o aspecto negativo do poder em Urbinati, o julgamento exerce o papel de aproximação ou de simpatia entre ideias da sociedade e decisões do Estado e, portanto, em última instância, estará sujeito à autoridade estatal. Outrossim, é preciso lembrar que a autora está tratando de uma sociedade aberta, livre e plural, na qual o julgamento político pode ser exercido por distintos atores e em diversas instâncias. "A igualdade política - como uma condição de legitimidade, um guia para o julgamento político e uma promessa a ser cumprida - é o ponto de referência em relação ao qual o processo político da representação democrática define seus objetivos, linguagem e projetos, e se submete ao julgamento crítico dos cidadãos" (URBINATI, 2006a, p. 6, tradução da autora). Contudo, diante da desigualdade material, cultural e política que impede a manifestação autônoma dos indivíduos, é preciso considerar que o acesso aos mecanismos de influência da sociedade civil e o julgamento crítico dos cidadãos também é desigual.

A ausência de um processo autorizativo é um problema que precisa ser enfrentado. 0 pensamento liberal moderno deixou como herança a ideia de consentimento voluntário como fundamento da legitimidade do governo e de suas decisões. A noção de consentimento é central para a igualdade, ao estabelecer que o voto de cada indivíduo tem exatamente o mesmo peso. Os problemas relacionados com essa igualdade já foram discutidos em outro momento (ALMEIDA, 2013). O que se quer ressaltar aqui é que a exclusividade desse tipo de autorização precisa ser repensada, haja vista os limites das eleições para seleção de "bons governantes" e para a representatividade democrática. De acordo com Urbinati (2006a), as eleições engendram a representação, mas não os representantes. Isso implica rever a noção de que a legitimidade é atributo exclusivo do procedimento eleitoral (status), para incluir a possibilidade de que seja construída de maneira substantiva, durante o processo de representação (qualidade) (Rosanvallon, 2009). A ideia de que a legitimidade é um processo, ou seja, não está dada, mas é contingencialmente buscada na qualidade do processo representativo, lança nova perspectiva para as análises empíricas sobre as formas de se estabelecer a prestação de contas e a responsividade (MENDONÇA, 2008; SAWARD, 2011). Nessa direção, a legitimidade é sempre precária, permanentemente questionada, dependente da percepção social da ação e do comportamento das instituições. Conforme 
ALMEIDA, D. R. Pluralização da representação política e legitimidade democrática...

destaca Parkinson (2003, p. 184), a legitimidade é um ideal regulatório, não um ponto fixo em uma escala. Nesse sentido, importa falar de processos de legitimação, nos quais a legitimidade é construída ao longo do tempo por meio do exame crítico da ação política.

A leitura de Young $(2000$, p. 128) vai ao encontro dessa perspectiva ao defender que o sentido normativo da representação requer uma avaliação do processo representativo, de acordo com as características do relacionamento entre representantes e representados. Para a teoria representativa, essa relação deve se pautar pela accountability e responsividade. Apesar de muito próximos, esses conceitos são distintos ${ }^{7}$. O primeiro inclui a prestação de contas e a capacidade de sanção dos representados a partir do veredito do voto e, o segundo, está relacionado à sensibilidade dos representantes à vontade dos representados (MIGUEL, 2005). A questão é que na ausência de institucionalização de obrigação de resposta e responsividade nos mecanismos de representação não eleitoral, alguns autores acabam por defender a inviabilidade de um relacionamento democrático (MIGUEL, 2011). A percepção da representação como relacionamento e não como sinônimo de eleições implica uma revisão da forma de pensar a accountability e a responsividade. Ao abrir espaço para outros atores com função representativa, a teoria contemporânea tem o desafio de discutir como se representa. Para isso, defendo que é fundamental prestar atenção nas diferenças entre atores e espaços de atuação.

Para Fox (2000), o casamento entre procedimentos democráticos e resultados é contingente. A presença de mecanismos institucionalizados de accountability não é garantia de seu pleno funcionamento ou de um governo eficiente, em termos, por exemplo, de igualdade econômica e governança accountable. A accountability é um processo sempre imperfeito e dependente da interação entre controles verticais e horizontais e diferentes modos de representação. A sociedade civil pode, por exemplo, empoderar os mecanismos horizontais de controle ao exercer pressão e expor abusos de poder. Além disso, pode agir indiretamente no fortalecimento das instituições de controle vertical, como a democracia eleitoral e a mídia independente. A accountability política é promovida tanto por instituições estatais quanto não estatais, e os resultados dependem frequentemente da interação entre as duas.

A dimensão relacional da accountability é a chave também para compreender o que pode encorajar a sociedade civil a prestar contas ao interesse público e a não reproduzir uma cultura elitista. A atenção ao tipo de organização e suas particularidades é fundamental na formulação de Fox (2000). Em organizações baseadas em vínculos associativos, embora a tendência de autonomização dos líderes de suas bases seja forte, como já expressava Michels (1982), ela não é insuperável. A existência de mecanismos internos de accountability horizontal nas organizações sociais, como instâncias intermediárias de participação, é um complemento crucial ao controle dos líderes. Esses grupos ou instâncias de coordenação ajudam no compartilhamento de informações, na geração de alternativas e contrapropostas e na formação de potenciais líderes. Os associados também têm a opção de saída da organização. Em organizações não associativas, tais como ONGs, a accountability pode se dar em diferentes direções. Um dos detaques é o controle mútuo entre organizações que funcionam em rede e o estabelecimento de hierarquias informais, que podem constranger a comportamentos accountables

\footnotetext{
${ }^{7}$ Embora accountability e responsividade sejam processos distintos, a análise que se segue neste artigo nem sempre faz uma distinção muito clara, tendo em vista a complementaridade entre eles. Neste sentido, mecanismos de prestação de contas, como a publicidade dada a um determinado tema, podem ajudar na construção de políticas mais responsivas. Logicamente, estes processos podem se reforçar mutuamente, o que não significa que isso ocorra de uma maneira automática. $\mathrm{O}$ exemplo mais claro é o próprio controle eleitoral que não redunda em imediata sensibilidade aos interesses dos representados.
} 


\section{OPINIÃO PÚBLICA, Campinas, vol. 20, no 1, abril, 2014, p. 96-117}

(SAWARD, 2006). Outros elementos que podem contribuir no controle público são indicadores de performance, meios de comunicação e justificações públicas de representatividade - especialmente utilizadas por grupos sem poder e que precisam conquistar influência (URBINATI E WARREN, 2008; LAVALLE, HOUTZAGER, CASTELLO, 2006b).

Deve-se salientar que os atores sociais podem gerar uma representação desigual, uma vez que não há como alcançar a igualdade abstrata presente nas eleições. As desvantagens de educação, renda e outros recursos distribuídos desigualmente podem se traduzir em sobre e/ou sub-representação (URBINATI E WARREN, 2008). Contudo, estas novas formas de representar têm a capacidade de apresentar discursivamente opiniões e vozes ausentes da dinâmica eleitoral. A saída para a democratização da representação não é a exclusão dos atores que exercem a representação discursiva ou temática de ideias, mas o aperfeiçoamento dos meios de justificação pública e de diálogo com os indivíduos e grupos representados.

Em relação à responsividade, o principal problema é a diminuição da soberania popular diante da impossibilidade de influência direta nos mecanismos de representação societal. Desse modo, a legitimidade da fala ou do agir no lugar do representado, de uma maneira sensível às suas demandas, não está posta no consentimento direto dos indivíduos, mas no processo representativo. Uma das propostas importantes nessa direção é aquela apresentada pela teoria feminista que aposta na presença de grupos que compartilham determinadas perspectivas sociais para a defesa de seus interesses (YOUNG, 2000). Embora os estudos deem ênfase na política eleitoral, por meio da defesa de cotas para mulheres e outros grupos excluídos, a noção de perspectivas sociais ajuda a pensar a representação da sociedade civil ao deslocar a responsividade para o campo do compartilhamento de algumas características e para a similitude de condições de vivência. Grupos tradicionalmente marginalizados poderiam contribuir para dar visibilidade pública às demandas de seus "semelhantes" e para a sensibilização dos representantes eleitos, na medida em que compartilham as formas de ver o mundo de seus representados, vinculadas a certos padrões, socialmente estruturados, de experiências de vida (MIGUEL, 2005). As perspectivas são importantes pontos de partida para a construção de interesses e não determinam em si o conteúdo da deliberação (YoUNG, 2000).

A representação descritiva é complementada por outras análises que destacam o papel da advocacy ou defesa do representado. Urbinati (2006b) salienta que o sentido da representação democrática é formado pela representatividade e pela defesa (advocacy). Comprometido com a causa dos representados, o representante deve ser capaz de reconstruir seu raciocínio para poder defendê-los de modo eficaz. Apesar da crítica do caráter elitista desse modelo (MIGUEL, 2011), a autora deixa claro que essa criação não se dá de maneira autonomizada do representado. A representação tem uma dimensão temporal que vai além da política do sim ou não e articula os representantes com os cidadãos por meio de um debate contínuo "ao projetá-los numa perspectiva orientada pelo futuro" (URBINATI, 2006b, p. 225). A responsividade é construída igualmente por meio da defesa de discursos, que são consistentes com a esfera pública (DRYZEK E NIEMEYER, 2008). Diferentemente da tradição liberal, cujo 


\section{ALMEIDA, D. R. Pluralização da representação política e legitimidade democrática...}

objeto da representação são os indivíduos, os autores defendem a representação de uma ampla gama de discursos, que possam contemplar os sujeitos em seus dilemas e tensões ${ }^{8}$.

Existem algumas dificuldades na operacionalização destas ideias pouco tematizadas pela literatura. Uma delas é a relação direta entre a pluralização de perspectivas e discursos e a democratização da representação. Sendo assim, argumento que esses são elementos que ativam a responsividade ou contribuem para gerar discussões que podem caminhar para a formação dos interesses dos envolvidos. Nesse sentido, a responsividade precisa ser avaliada a partir da dimensão processual e construtiva. Uma representação responsiva aos interesses ${ }^{9}$ do representado pode ter como ponto de partida o compartilhamento de perspectivas ou a presença de perspectivas ou a defesa de ideias, mas esse processo só se completa na manutenção do relacionamento entre representantes e representados. A representação política é um processo criativo, no qual o constituinte nunca está dado, como pressupõe o momento eleitoral, mas é construído politicamente. Ademais, se o aspecto criativo é importante na representação, ele não pode se dar sem atenção aos significados compartilhados numa sociedade e à dimensão cultural. Essa construção não pode ser arbitrária no sentido de desrespeitar tendências do tecido social. Uma demanda representativa não tem sentido, se não for ouvida, vista ou decifrada por seu público-alvo, por aqueles a quem se destina a atrair e convencer (SAWARD, 2006, p. 312).

Novamente, o relacionamento democrático só pode ser avaliado a partir das especificidades dos espaços e atores. A representação descritiva operacionalizada a partir das cotas eleitorais, diferentemente da representação da sociedade civil, funciona como um complemento à accountability, uma vez que "os representantes continuam dependentes do voto popular, mas os interesses de determinados grupos serão levados em conta graças à presença de um contingente de seus integrantes nos espaços decisórios" (MIGUEL, 2005, p. 35). Já a representação mimética ou descritiva, adotada em experimentos tais como pesquisas deliberativas ou assembleia de cidadãos, com o respaldo de mecanismos aleatórios de seleção ${ }^{10}$ (FISHKIN, 2009; BROWN, 2006), em geral, dispensa o controle vertical do cidadão. O que não exclui a possibilidade de alternativas criativas para o controle. $O$ referendo adotado na Assembleia de Cidadãos de British Columbia ${ }^{11}$, responsável por discutir o sistema eleitoral, é um bom exemplo de como contrabalançar a opinião que emerge no processo deliberativo com a recomendação direta da população (BROWN, 2006). Por fim, não se pode esquecer que esses atores

\footnotetext{
${ }^{8}$ Os autores chegam a propor a constituição de Câmaras Discursivas, que agreguem representantes de diferentes discursos. Os desafios de operacionalização da representação discursiva, tanto na promoção do choque de discursos, quanto na própria noção de discurso, podem ser vistos na análise de Mendonça (2010).

${ }^{9}$ A ideia de que os representantes devem agir no interesse de seus constituintes é marcada por ambiguidades e imprecisões. Existem incertezas e divergências teóricas em relação ao modo em que são formados e reconhecidos (MıGUEL, 2011). Este artigo não parte de uma noção de interesses como previamente determinados e (sempre) conscientemente reconhecidos. Afasta-se tanto da corrente utilitarista que aposta na centralidade dos interesses egoístas quanto da visão agregativa da política, que percebe as eleições como momento de agregação das preferências e interesses. Nesse sentido, representar é uma atividade que está ligada tanto à defesa do interesse ou da preferência previamente existente, como à criação desse interesse ou realidade. Em contraponto à visão utilitarista, Miguel (2011) defende que é possível reconhecer tanto a possibilidade de manipulação quanto a ausência de um "interesse verdadeiro" objetivamente identificável, posição paradoxal, mas que leva em conta a autonomia diferenciada dos diversos sujeitos sociais na produção de suas próprias preferências e interesses.

10 Há diferenças significativas entre os desenhos deliberativos. Fung (2004) chama essas variações de minipúblicos e destaca sete características de diferenciação: objetivos, mecanismos de seleção, tema da participação, como ocorre a deliberação, momento ou periodicidade, por quê?, poder decisório e monitoramento.

11 A Assembleia de Cidadãos de British Columbia foi um experimento convocado pelo governo local para discutir o sistema eleitoral da província. A Assembleia foi composta por 160 membros, selecionados aleatoriamente a partir da lista de eleitores. Os membros se reuniram por 9 meses, num processo de aprendizado, escuta e deliberação. No final, as propostas foram submetidas a um referendo, a fim de balancear a opinião dos eleitores e dos participantes.
} 
representam perante o poder político, diretamente autorizado a tomar decisões vinculantes. 0 Estado teria a função de equilibrar a representação igualitária dos ausentes com a pluralidade da sociedade civil (ABERS E KECK, 2008a).

A revisão do conceito de representação política aponta para a pluralidade do exercício da soberania popular, seja como expressão da vontade no voto, seja por meio da representação que se constrói na prática dos atores sociais que falam e agem "pelos" outros ${ }^{12}$. Diante da natureza intrinsecamente dual e desigual da representação, inclui presença e ausência do representado (PITKIN, 1967), a atenção ao relacionamento entre representantes e representados é essencial para a legitimação democrática desse processo. Sendo assim, sugeriu-se, nesta seção, olhar para a representação da sociedade civil em perspectiva, o que implica avaliar as particularidades das experiências e o que elas mudam na forma de exercer a accountability e a responsividade.

\section{Instituições Participativas no Brasil: accountability e responsividade}

As instituições participativas (IPs) já foram estudadas a partir de diferentes perspectivas e as análises empíricas revelaram um conjunto de variáveis que interferem na qualidade da interação Estado e sociedade. Ainda que pouco orientadas pelo papel representativo da sociedade civil, há relativo consenso sobre alguns fatores considerados essenciais para o sucesso ou fracasso das IPs, entre os quais destaco o desenho institucional (FARIA, 2007; AVRITZER, 2003); as diferenças nas áreas de políticas públicas (CÔRTES, 2002; FUKS E PERISSINOTTO, 2006); a densidade associativa e as relações políticas na sociedade civil (WAMPLER E AVRITZER, 2004) e a existência ou não de governo ou coalizões com projetos participativos (WAMPLER, 2011; CUNHA, 2013). Essas são algumas dimensões que ajudam a compreender sob que condições a representação pode ser democrática. A possibilidade de as IPs consubstanciarem as propostas de inclusão e revisão da construção da legitimidade democrática e de controle dos cidadãos sobre políticas é impactada por estes fatores.

Apesar do viés participativo e deliberativo, as análises paulatinamente indicaram a dinâmica representativa dessas instituições, tendo em vista, por exemplo, a representatividade dos atores, em termos da pluralidade dos participantes e vínculos com organizações sociais, e a dinâmica deliberativa, que envolve a defesa de temas e interesses da sociedade. Nos últimos anos, a representação política exercida por atores sociais passa a orientar os estudos na área, influenciados tanto pelas evidências empíricas quanto pelo debate internacional.

Lavalle et al (2006a, 2006b) apresentam o conceito de representação virtual ou presuntiva, inspirados na literatura contemporânea e moderna, especialmente em Burke, e nos argumentos utilizados pelas organizações sociais para destacar as especificidades da representação coletiva exercida no país. Para os autores, a autenticidade da representação - sua representatividade - está relacionada com a existência de um compromisso genuíno com os interesses dos representados, embora não formalmente reconhecido ou aceito. Atores da sociedade civil exerceriam o papel de advocacy perante o poder público. Na ausência de autorização, os mecanismos de accountability ganhariam força na sustentação de relações democráticas. Os autores, porém, não diferenciam a representação de

\footnotetext{
12 Ao declarar que a sociedade civil fala "pelos outros" quero marcar a diferença com a representação eleitoral, em que os representantes agem em nome de outros, tendo em vista a autorização expressa dos indivíduos. Os atores coletivos e indivíduos que atuam na esfera pública, geralmente, são autoautorizados (URBINATI E WARREN, 2008) e, portanto, falam por alguém.
} 
ALMEIDA, D. R. Pluralização da representação política e legitimidade democrática...

organizações sociais que atuam como intermediárias dos cidadãos com o poder público ou que prestam serviços, daquela exercida no interior das chamadas instituições participativas, que não exclui um processo de autorização. Tampouco discutem os problemas de operacionalização da prestação de contas em instituições com vínculos diretos com o Estado e cuja participação não está acessível a todos os indivíduos.

Avritzer (2007) parte da crítica à teoria de Lavalle et al (2006a), Urbinati (2006a) e Dryzek e Niemeyer (2008) para apresentar sua proposta de legitimidade da representação nas instituições participativas brasileiras, fundada na afinidade temática. O que os atores nas IPs estão defendendo não são discursos ou pessoas, mas temas, baseados na experiência participativa e temática adquirida ao longo do histórico de envolvimento com a política. A afinidade temática é o componente que legitima a representação nos conselhos e outras IPs, mas o autor deixa de considerar os problemas do relacionamento entre representantes e representados.

Não obstante a tentativa de diferenciar a representação de organizações sociais ou atores coletivos daquela praticada no contexto internacional, esta literatura deixa escapar algumas dimensões importantes para o processo de legitimação democrática. Destaco principalmente a necessidade de ir além de uma compreensão da representação focada exclusivamente nos atores (seu histórico de participação ou argumentos utilizados para justificar sua legitimidade) e mirar nas instituições participativas e suas interações com outros espaços e atores. Ademais, deve-se levar em conta sua inserção institucional que tem repercussão na forma como os atores são incluídos e no tipo de poder que mobilizam. Essas características influenciam diretamente a capacidade dos atores serem accountables e responsivos ao público que dizem representar. Como defendido por Fox, a accountability depende dos diferentes modos de representação e da interação entre eles.

Em relação à accountability, Lavalle e Isunza Vera (2010) avançam na identificação de diferentes interfaces entre Estado, organizações sociais e cidadãos, com várias funções e direções de controle social sobre as políticas desempenhadas pelo governo. Além dos modelos horizontais e verticais de controle, os autores incluem os dispositivos de prestação de contas societal pró horizontal ou pró vertical (cuja mobilização da sociedade civil se dá em direção às agências horizontais de controle em busca de responsabilização dos atores estatais ou tentando influenciar a sociedade e seu voto, respectivamente); transversal societal (relação das organizações sociais diretamente com outro ator estatal); transversal cidadã (cidadãos atuam dentro do aparelho estatal); cidadã pró horizontal (cidadãos ativam as agências de controle horizontal mediante queixas) e, finalmente, prestação de contas societal cidadã, como a que ocorre nas instituições participativas (representantes da sociedade prestam contas àqueles em cujo nome falam). Essas relações podem se basear em atos de informação, poder/domínio ou representação.

Recentemente, Lüchmann (2012), apoiada na teoria de sistemas deliberativos ${ }^{13}$, sugere pensar a representação nas IPs a partir da dinâmica mais ampla das instituições. Propõe resgatar a importância da dimensão da accountability institucional, deslocando o foco da prestação de contas do indivíduo. Para isso, deve-se olhar para os impactos desses espaços nas estruturas governamentais, bem como para as relações (institucionais) do conselhos com o ambiente social. Para a autora, a accountability precisa ser

\footnotetext{
13 Para aprofundamento da discussão sobre sistemas deliberativos, ver: Parkinson e Mansbridge (2012).
} 


\section{OPINIÃO PÚBLICA, Campinas, vol. 20, no 1, abril, 2014, p. 96-117}

pensada de forma menos personalizada (accountability dos atores sociais) e mais institucionalizada, ou seja, focada no controle institucional sobre os governos e nas relações das IPs com a sociedade, especialmente os setores mais diretamente afetados. Essa análise se coaduna com a proposta aqui defendida, embora considere que não é possível deslocar por completo a dimensão do controle público do indivíduo que representa nas IPs. A observação das reuniões do Conselho Nacional de Assistência Social, no ano de 2013, revelou que o debate da representação política é uma das preocupações dos conselheiros. Em suma, questiona-se atualmente se a responsabilização dos atos é do conselheiro ou da entidade a qual representa ${ }^{14}$.

Apesar das lacunas na teoria sistêmica para a compreensão de quais são os fatores que contribuem para a articulação entre os espaços e atores (CUNHA E ALMEIDA, 2013), existem avanços no estudo dos conselhos e outras IPs a partir do olhar para a inserção institucional e a interação com outras esferas. $\mathrm{O}$ que este artigo ressalta é a necessidade de avaliar a accountability e a responsividade levando em consideração tais características. Diferentemente dos indivíduos ou organizações e movimentos sociais que são, primordialmente, dependentes do julgamento público, como discutido na seção anterior, nas IPs, a legitimação é um processo que deve levar em conta 3 direções: a esfera estatal, os cidadãos impactados pela política e as organizações e movimentos sociais que integram tais instituições.

Essa distinção é importante devido ao caráter híbrido das IPs - frequentemente destacado na literatura nacional - e à dupla função da representação. Como postulam Lavalle et al (2006a), a representação coletiva no país envolve a representação perante o poder, visando regulá-lo socialmente, e a representação no poder, comprometida com governar e impor obrigações sobre a população, se for necessário. Ou seja, nos espaços informais de influência da sociedade civil, a representação se exerce perante o poder político, responsável e autorizado a tomar as decisões. Já a representação nos espaços de formulação de políticas públicas no Brasil, como conselhos, comitês de bacia hidrográfica, orçamentos participativos, envolve a representação direta de temas, discursos e políticas. Esses atores recebem autorização para tomar decisões em nome das pessoas que serão afetadas pela política. A sociedade civil é chamada para induzir o controle público dos representantes, por meio da pressão nas demais agências de controle, e para assumir um papel mais ativo na deliberação sobre políticas que afetarão indivíduos não participantes. Considerando a composição das IPs, geralmente atores coletivos escolhidos a partir da eleição ou indicação no interior de entidades civis, para além do Estado e dos cidadãos, as organizações sociais são outro elo importante na geração do controle e da responsividade.

A Figura 1 é uma tentativa de ilustrar como as instituições participativas intersectam com as esferas estatal e societal. De acordo com Hendriks (2006, p. 500), existem 3 formatos de esferas deliberativas: a esfera do Estado e suas instituições (microesfera deliberativa), especialmente órgãos do poder Executivo, parlamento, burocracia e partidos políticos. Na figura ela é representada por uma linha contínua e um preenchimento mais denso na cor, que indicam uma esfera formal de deliberação menos porosa à participação dos distintos atores da sociedade civil. As linhas tracejadas indicam a porosidade das esferas da sociedade (macroesfera discursiva) em relação aos interesses alternativos ou marginalizados ou aos interesses mais delimitados da esfera do mercado. Inclui desde grupos mais ou menos organizados - movimentos, ativistas, redes civis ou mídia, mas também grupos de interesse e

\footnotetext{
14 Observação dos pesquisadores que integram a pesquisa "A interação das arenas deliberativas nacionais de Assistência Social", coordenada pela autora. Programa de Iniciação Científica/CNPQ/UnB.
} 


\section{ALMEIDA, D. R. Pluralização da representação política e legitimidade democrática...}

corporações ·, até cidadãos que se engajam com o Estado como indivíduos. As instituições participativas situar-se-iam no que Hendriks denomina de esferas discursivas mistas com relativa porosidade aos distintos interesses e com composição variada em termos de atores, desde cidadãos individuais, até grupos de interesse, ativistas, mídia, técnicos governamentais, parlamentares e organizações da sociedade civil.

Figura 1

Representação política nas Instituições Participativas no Brasil

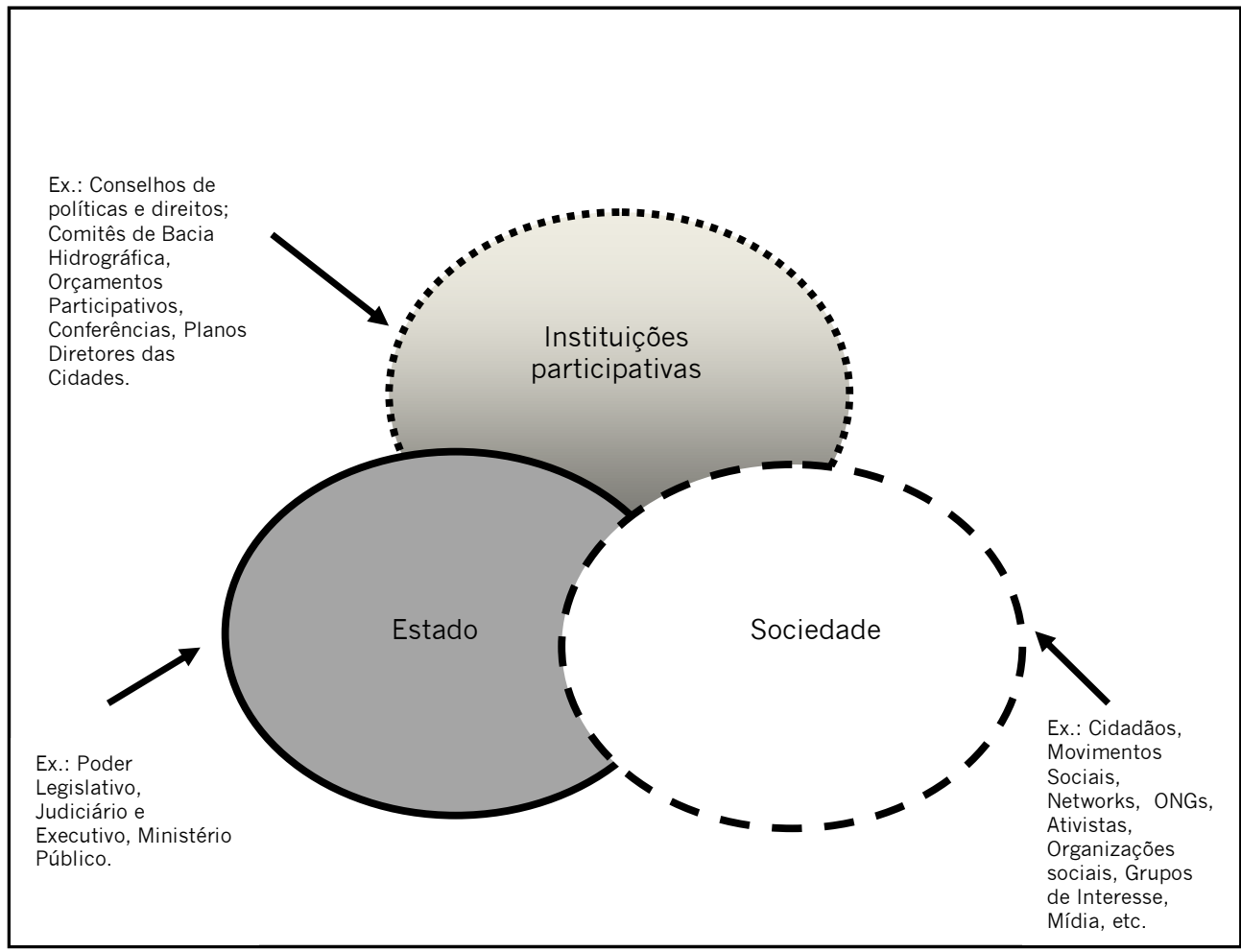

Fonte: ALMEIDA (2011)

A legitimidade democrática nas instituições participativas é dependente do relacionamento entre representantes e representados que circulam nos distintos espaços micro, mistos e macro, respectivamente o Estado (atores governamentais e burocracia que interagem com as instituições participativas), outras instituições participativas que compõem o sistema, e a sociedade em geral (organizações sociais e os indivíduos). Com isso, não pretendo afirmar que as modalidades de representação mais informais não precisam ser pensadas a partir da articulação nas diferentes esferas, apenas destacar as ambiguidades e complexidades dessa representação perante o poder e no poder. Algumas diferenças da representação informal e não institucionalizada são a relativa independência de ação em relação ao controle do Estado e a "relativa abertura" - haja vista as desigualdades estruturais que incidem na autonomia dos indivíduos - para que os diferentes discursos e perspectivas possam se manifestar na esfera pública. 
Já nas IPs, a inserção institucional e o poder decisório sobre políticas públicas são acompanhados de mecanismos de autorização. Desse modo, "quem são os incluídos" é uma questão essencial para discussão da legitimidade democrática, pois define quem são os participantes e qual o público ao qual devem prestar contas e ser responsivos. Primeiro, a determinação do público afetado e a definição de quais são os representantes que têm direito à vaga nas IPs estão diretamente relacionadas com as características da área de política pública e com o vínculo associativo. A variedade dos arranjos institucionais no país cobre igualmente uma ampla gama de temáticas, como saúde, educação, assistência social, mulheres, meio ambiente e outros. Além das questões diretamente relacionadas ao orçamento público, bens e serviços, e ao planejamento das cidades. A transversalidade de temas e complexidade das questões pode dificultar ainda mais a definição do público representado, mas em geral é possível visualizar grupos de pessoas diretamente envolvidas com as políticas deliberadas. A multiplicidade das pessoas afetadas e a complexidade das políticas deveriam, por conseguinte, influenciar a definição dos grupos que podem participar destes espaços. Esta é uma orientação presente nos normativos que regulamentam, por exemplo, a composição de conselhos de saúde e a composição de comitês de bacia hidrográfica. Porém, a inclusão das organizações e movimentos sociais é um ponto que precisa ainda de maior atenção. As IPs tendem a não incluir ou estar abertas à pluralidade de demandas, afinidades e perspectivas. O risco de reprodução de um elitismo político é real e comprovado em várias pesquisas empíricas. Dependendo do perfil da política, os espaços têm limitada participação de grupos com poucos recursos materiais e políticos. Esta é uma dimensão que precisa ser aperfeiçoada, a fim de que as IPs possam reivindicar representar interesses, perspectivas e opiniões compartilhados ou publicamente justificáveis perante as pessoas afetadas pela política. A construção de demandas legítimas e responsáveis passa por uma preocupação com a forma de incluir estes atores.

Atualmente os processos de seleção de representantes da sociedade civil são muito variados. Alguns espaços, como conselhos de políticas, adotam a eleição entre um público restrito, que possui vinculação com entidades e organizações sociais, ou indicação de seus membros. Em alguns momentos, tais organizações já estão delimitadas por lei ou regimento interno. Em outros, o processo é renovado a cada mandato. Nos OPs, há eleição entre os participantes para os delegados, responsáveis pela fiscalização e acompanhamento das obras. Já comitês de bacia hidrográfica também adotam eleições de entidades, mas geralmente há requisitos legais e temáticos que precisam ser preenchidos para ter o direito de participar. Avaliar tais particularidades e a possibilidade ou não de renovação das lideranças, bem como a existência de disputa dos distintos interesses é crucial para a qualificação desta representação como democrática. Em trabalho anterior, sugeri olhar para quatro dimensões da inclusão: i) quais são os segmentos e categorias que têm assento; ii) quem são estes atores em termos de características socioeconômicas; iii) como são selecionados e iv) quais são as regras que habilitam quem tem direito a participar (ALMEIDA, 2011).

No que diz respeito à interseção das IPs com a esfera estatal, é possível perceber duas consequências diretas para a representação. Primeiro, há uma mudança na forma de exercer o controle social das decisões governamentais. Mais do que pressionar o Estado, mobilizar os cidadãos ou ativar as agências de controle horizontal, organizações sociais têm a oportunidade de controlar diretamente o Estado quando participam do processo decisório. Segundo, a responsividade dos representantes eleitos e não eleitos é impactada pela troca de informações e construção coletiva dos interesses. De acordo com 
ALMEIDA, D. R. Pluralização da representação política e legitimidade democrática...

Wampler, um conjunto diverso de IPs - conselhos, conferências, OPs, etc. - é a base de uma arquitetura institucional que une os líderes de diferentes organizações da sociedade civil, ajudando essas últimas a construir e manter "laços de solidariedade" com funcionários governamentais (ALEXANDER, 2006 apud WAMPLER, 2011, p. 157). Os "laços de solidariedade" são cruciais, pois permitem aos líderes, que de outra forma estariam isolados, desenvolver laços com indivíduos que tenham preocupações e reivindicações semelhantes. Tendo em vista que a sombra das eleições está sempre presente, a sociedade civil usa as IPs para tentar induzir o governo a atender as suas demandas e os governantes e seus funcionários usam as IPs para atender às demandas coletivas e individuais dos participantes, mas, ao mesmo tempo, para recolher informações sobre suas habilidades de mobilização. Desse modo, as instituições participativas têm o papel de atrair novos olhares e demandas para o sistema representativo.

Os riscos estruturais, apontados por Habermas (2003), relacionados à possibilidade de colonização do discurso público por interesses estratégicos são um dos motivos destacados para a recusa de fóruns estruturados de deliberação pública dentro do Estado. As razões para a rejeição a fóruns institucionalizados são variadas, como a preocupação com a limitação de seus pontos de vista e preferências, o medo de cooptação e posterior marginalização e a possibilidade de dominação ideológica (HENDRIKS, 2006). Além disso, a dificuldade dos agentes governamentais de partilhar o poder leva à fraqueza no controle social e à dificuldade de implementação das políticas deliberadas (TATAGIBA, 2002). Pesquisa do Instituto de Pesquisa Econômica Aplicada (IPEA, 2013) $)^{15}$, realizada em 21 conselhos nacionais, revela que, na opinião dos conselheiros nacionais, o impacto do conselho sobre o Congresso e as políticas públicas de outros ministérios é pouco significativo (52,6\% e 47,3\%, respectivamente). Porém, a interação parece ser maior com o ministério ou secretaria da área de política pública diretamente relacionados aos conselhos. Essas percepções sugerem que existem aspectos da articulação entre diferentes políticas e áreas de política pública que precisam ser considerados na cadeia de responsividade. Principalmente, considerando a natureza transversal das políticas públicas.

Quanto à interação com o contexto misto, é preciso considerar o relacionamento representativo a partir da inserção institucional das IPs e da organização federativa das políticas públicas no Brasil. Conselhos e conferências são um bom exemplo de arenas mistas que se conectam, nos diferentes níveis de governo, e cuja qualidade do processo deliberativo no interior desses espaços influencia a capacidade dos atores coletivos e das respectivas instituições serem accountables e responsivos ao interesse público. A dinâmica interativa entre conselhos e conferências envolve a organização e deflagração dessas pelos conselhos, desde o nível local até o nacional, e o consequente encaminhamento das deliberações finais aos respectivos conselhos, que devem sancioná-las (CUNHA E ALMEIDA, 2013). As conferências são espaço de controle das políticas públicas, ao mesmo tempo em que são responsáveis pela formulação de macro diretrizes para a área. Seu processo escalonado sugere a oportunidade de construção de políticas responsivas, a partir da consideração dos diferentes contextos. A interação com os conselhos não se limita a sua organização e posterior encaminhamento das deliberações. A leitura do relatório final da VII Conferência Nacional de Assistência Social revela a preocupação com a participação popular nos conselhos dos diferentes níveis da Federação, o que sugere a mútua influência entre essas esferas mistas. Os estudos sobre as dinâmicas das conferências e sua relação com os conselhos estão ainda na

\footnotetext{
${ }^{15}$ Pesquisa realizada com titulares e suplentes dos conselhos nacionais, representantes do governo e da sociedade civil.
} 


\section{OPINIÃO PÚBLICA, Campinas, vol. 20, no 1, abril, 2014, p. 96-117}

fase inicial (FARIA, SILVA e LINS, 2012; CUNHA E ALMEIDA, 2013). Mas sabe-se que existem dificuldades de efetivação das deliberações, devido a sua dependência, por exemplo, da vontade política, do andamento nos órgãos governamentais e da implementação nos diferentes contextos. Ademais, a prestação de contas ainda é incipiente, tanto para o público participante, tendo em vista as dificuldades de acompanhamento e monitoramento, quanto para a sociedade em geral - a publicização desses processos para além dos muros das IPs é precária.

No que tange à relação das IPs com o contexto macro, existem diferenças no relacionamento dos atores e das instituições com as organizações e movimentos sociais e com os cidadãos. As regras de composição dos conselhos, por exemplo, determinam que a participação está atrelada à vinculação a organizações e movimentos sociais ${ }^{16}$. Conselheiros fazem parte de uma determinada policy community, a qual compartilha um senso de identidade e sentimento de pertencimento e afinidade com a temática a ser deliberada (AVRITZER, 2007). Essas conexões e interações possibilitam que eles interajam e se conheçam mutuamente, compartilhando ideias, opiniões e discursos, que são publicamente apresentados e testados nas diversas esferas (CUNHA E ALMEIDA, 2013). Desse modo, a responsividade pode ser ativada pela afinidade, bem como a proximidade com algumas organizações sociais abre a possibilidade de um controle das ações do conselho.

Essas expectativas são confirmadas em várias pesquisas que mostram que os conselhos e conselheiros prestam contas às suas bases e, ou mantêm um fluxo discursivo com os seus pares por meio das conexões que estabelecem nos diferentes espaços de representação dos quais participam. A título de ilustração, os dados do IPEA (2013, p. 38) indicam que os conselheiros têm como interesse prioritário a coletividade (39\%), mas a representação de grupos específicos, por meio das entidades da sociedade civil, está presente em grande parte das respostas. Entrevistados declaram defender prioritariamente os "interesses da minha instituição" (17\%) e os "interesses do meu setor" (12\%), opções que totalizam quase um terço das respostas válidas. Apesar do alto nível de respostas que envolvem a defesa de interesses da coletividade, para o segundo nível de prioridade é forte a relação com as entidades. Os interesses apontados como segunda prioridade são os "interesses do meu setor" (21\%), seguido de "interesses de redes ou movimentos" (17\%) e "interesses da instituição" (16\%). Apesar de positiva, esta relação também pode ter o efeito de excluir outras vozes e discursos que não se coadunam com aqueles defendidos por seus pares. As informações sobre prestação de contas indicam que existe um fluxo discursivo ou de informações entre os atores e suas "bases", seja por meio de emails, conversas pessoais ou reuniões.

Quando o foco são os cidadãos, que em última instância serão afetados pelas políticas públicas, existem alguns mecanismos que podem ajudar na legitimação do processo representativo. 0 debate internacional destaca a importância dos representantes da sociedade civil estabelecerem um movimento constante de informação, poder e representação com o público mais amplo que será beneficiário de determinada política. Embora não prestem contas a um constituinte individual, atores coletivos oferecem um tipo de prestação de contas discursiva ao público, uma forma de accountability que pode complementar o controle eleitoral. A prestação de contas pública e a responsividade podem ser efetivadas por meio de acordos que reflitam a opinião pública refinada por meio do processo de debate.

\footnotetext{
16 Uma exceção são os Conselhos de Assistência Social que preveem a participação do usuário do sistema. Embora, em geral, a operacionalização da participação desses atores seja um problema na área.
} 
ALMEIDA, D. R. Pluralização da representação política e legitimidade democrática...

No caso das IPs, é possível vislumbrar também um tipo de controle direto da sociedade, quando a população demanda a um conselho de saúde, por exemplo, uma atuação em determinado problema nos serviços prestados no município. Ou quando a população de um bairro fiscaliza e cobra dos delegados do OP a realização das obras eleitas durante o processo participativo.

As IPs possuem um elo mais distante com a população, haja vista as características do processo de formulação de políticas públicas e o atrelamento da participação à representação de atores coletivos. Assim como discutido para as experiências informais, é preciso que tais espaços invistam no desenvolvimento de canais permanentes de interação, como meios de divulgação mais amplos de suas ações (internet, jornal, rádio e televisão). Essa é uma dimensão que parece ainda carecer de aperfeiçoamento. As informações sobre a prestação de contas das IPs indicam que os conselheiros percebem que há pouca ou nenhuma influência do conselho em relação à opinião pública sobre o tema (53\%) (IPEA, 2013). Ademais, quando se questiona sobre as formas de comunicação utilizadas pelos conselheiros para divulgar as ações do conselho, os meios de longo alcance e que poderiam constituir uma comunicação mais ampla e difundida com a sociedade, como homepage e perfis em redes sociais, apresentam pouca expressividade.

\section{Considerações finais: lições teóricas e práticas}

A discussão sobre as mudanças na representação política, que começaram a ser gestadas no período de redemocratização brasileira, teve o objetivo de mostrar a pluralização nos modos de se fazer representar no país, a qual contrasta com os períodos precedentes. O Brasil é diferente não só em relação a sua própria história, mas também quando comparado a outros países, tanto na sua forma de conciliar participação com governo representativo, quanto na extensão em que a sociedade civil passa a partilhar o poder decisório. As instituições participativas conectam a sociedade ou o público mais geral com o Estado a partir da representação de organizações sociais.

A nova compreensão da representação na teoria política contemporânea não escapa, porém, do desafio inerente aos seus próprios termos, qual seja, tornar presente a ausência. Tampouco pode se furtar de discutir suas essências aristocrática (MANIN, 1997) - os governantes possuem características sociais distintas dos governados - e assimétrica (MICHELS, 1982) - tendência à diferenciação funcional e distanciamento - que impõem dificuldades para lidar com o ideal de representação democrática "pitkiniano", agir no interesse do representado de uma maneira responsiva a ele. Esse ideal, quando transportado para as experiências de representação extraparlamentares, tem imposto sérias barreiras para os revisores do conceito. Como avaliar a legitimidade da representação da sociedade civil e quais são as especificidades no exercício da accountability e responsividade nas instituições participativas brasileiras são questões que este artigo buscou responder.

Em relação à primeira indagação, propôs-se pensar a legitimidade democrática como um construto, não um atributo de determinado procedimento ou ação. O que não implica a negação da importância dos procedimentos democráticos para a construção de resultados mais justos e igualitários. Mas a percepção de que o relacionamento democrático, que envolve atenção aos interesses dos representados e controle público, não é resultado exclusivamente da presença de mecanismos institucionalizados ou da vontade expressa na autorização, mas passa pela dimensão do julgamento público. Até aqui não há alterações em relação à teoria clássica de representação. A accountability, 


\section{OPINIÃO PÚBLICA, Campinas, vol. 20, no 1, abril, 2014, p. 96-117}

apesar de um processo imperfeito, mesmo nas democracias eleitorais mais consolidadas, é um elemento essencial do processo representativo. A diferença está relacionada com a forma de operacionalização deste julgamento.

Urbinati traz vigor a esta discussão ao postular o aspecto dual da soberania: vontade e julgamento. Uma vez que a representação não é apenas um ato da vontade expressa no consentimento, mas algo que se renova por meio do julgamento político, abre-se caminho para a retomada na teoria política de outros modos de representação. Nestes casos, há uma retomada do ideal de responsividade e accountability da representação democrática, de uma maneira descolada do momento de constituição do representante. As críticas de abandono da soberania popular devem ser levadas a sério, sem necessariamente engessar as interpretações sobre o exercício de facto de representação da sociedade civil.

Entre as questões destacadas para o desenvolvimento da accountability, o artigo elencou mecanismos internos de controle nas associações, justificações públicas de representatividade - que permitam o teste público dos representantes e a inclusão dos diferentes grupos e indivíduos -, controle mútuo entre organizações, indicadores de performance e meios de comunicação. Já entre os instrumentos que podem promover a responsividade, de maneira independente da presença de sanção ou punição do representante, análises recentes apostam na sensibilização do representante a partir do compartilhamento de perspectivas sociais, bem como da defesa de ideias e discursos. Os diferentes relacionamentos representativos precisam ser avaliados a partir de sua interdependência e das particularidades dos encontros entre Estado e sociedade. $\mathrm{O}$ artigo lembrou, finalmente, que as fontes de julgamento informais da sociedade civil exercem a representação perante o poder político, que em último caso será responsável pelo processo decisório.

No que concerne às IPs brasileiras, com poder de voz e voto, as dificuldades de operacionalização de um relacionamento democrático estão diretamente relacionadas com duas características: sua inserção institucional e interação com as esferas estatal e societal. Não obstante a diversidade de análises sobre a representação da sociedade civil, este artigo propôs jogar luz sobre essas características, tendo em vista as implicações para a accountability e responsividade. A inserção institucional responde pela dupla função da representação nas IPs - perante o poder e no poder - o que leva à possibilidade de que os atores construam políticas responsivas e controlem o Estado a partir do trânsito nas esferas governamentais. Ao mesmo tempo, as IPs não dispensam um processo de autorização, no qual a definição de quem é incluído deve considerar a área de política pública e o vínculo associativo. Com isso, é possível vislumbrar o tipo de público afetado pela política e direcionar as ações das IPs. Todavia, o artigo mostrou que o processo autorizativo pode também gerar problemas, pois ao limitar a participação afeta a pluralidade representada e, portanto, quais são os interesses e afinidades que serão consideradas nas decisões. Destacou também as dificuldades, há muito tempo levantadas pela literatura, de partilha de poder nos encontros entre Estado e sociedade.

Por fim, o hibridismo das IPs põe em destaque o aspecto relacional da prestação de contas e da responsividade. Mais do que estar sujeitos ao julgamento público, esses atores e espaços estão imersos numa rede de relações políticas e sociais que impactam o relacionamento democrático. Sendo assim, as interações com os agentes governamentais, as organizações sociais e os cidadãos são fatores que precisam ser considerados no processo de legitimação das IPs. Alguns exemplos foram 
ALMEIDA, D. R. Pluralização da representação política e legitimidade democrática...

apresentados no artigo, o que não cobre a complexidade das interações. O que se pretendeu foi apenas reforçar a necessidade de situar as IPs nesta rede ampla de representação, a fim de compreender suas possibilidades e limites no processo de prestação de contas e responsividade.

\section{Referências Bibliográficas}

ABERS, R; KECK, M. E "Representando a diversidade: Estado, sociedade e 'relações fecundas' nos conselhos gestores". Caderno CRH, Salvador, vol. 21, n. 52, p. 99.112, jan./abr. 2008a.

"The collective constitution of representative authority in Brazilian river basin Committees". Conference Rethinking Representation: A North South Dialogue. Bellagio, Bellagio: Bellagio Study and Conference Center, mimeo, 2008b.

ALMEIDA, D. R. "Repensando representação política e legitimidade democrática: entre a unidade e a pluralidade". Tese de Doutorado em Ciência Política. Universidade Federal de Minas Gerais, Belo Horizonte, 2011.

"A relação contingente entre representação e legitimidade democrática sob a perspectiva da sociedade civil". Revista Brasileira de Ciências Sociais, vol. 28, n 82, p. 45.66, jun. 2013.

Alvarez, S. E.; Dagnino, E.; Escobar, A. (Org.). Cultura e política nos movimentos sociais latino-americanos: novas leituras. Belo Horizonte: UFMG, 2000.

ARAUjo, C. "Representação, soberania e a questão democrática". Revista Brasileira de Ciência Política. Brasília, n 1 , p.47.61, jan./jun. 2009.

AVRITZER, L. O orçamento participativo e a teoria democrática: um balanço crítico. In: inovação democrática no Brasil. São Paulo: Cortez, 2003. ; NAVARRo, Z. (Org.). A

"Sociedade civil, instituições participativas e representação: da autorização à legitimidade da ação". Dados . Revista de Ciências Sociais. Rio de Janeiro, vol. 50, n³, p. 443.464, 2007.

Participatory institutions in democratic Brazil. Washington, D.C.; Baltimore: Woodrow Wilson Center; John Hopkins University, 2009.

Brown, M.B. "Survey Article: citizen panels and the concept of representation". The Journal of Political Philosophy, vol.14, n'2, p. 203.225, 2006.

CAStiglione, D.; WarRen, M. E. "Rethinking democratic representation: eight theoretical issues". Rethinking Democratic Representation Workshop. Columbia, University of British Columbia, 2006. Disponível em: <http://www.politics.ubc.ca/fileadmin/user_upload/poli_sci/Faculty/warren/Rethinking_Democratic_Representation_M ay_2006.pdf>. Acesso em: 20 jun. 2010.

CôRTES, S. M. V. Participação de usuários nos conselhos municipais de saúde e de assistência social de Porto Alegre. In: PeRISSInotTo, R.; Fuks, M. (org.). Democracia: teoria e prática. Rio de Janeiro: Relume Dumará; Curitiba: Fundação Araucária, 2002.

CunHA, E. S. M. Efetividade deliberativa de conselhos de Assistência Social. Jundiaí: Paco Editorial, 2013.

; ALMEIDA, D. R. "Sociedade civil e representação nas arenas deliberativas da Assistência Social no Brasil". XXXI Congress of the Latin American Studies Association. Washington D.C., 2013. Disponível em: <https://lasa4.lasa.pitt.edu/members/congress-papers/lasa2013/index.asp>. Acesso em: 19 set. 2013.

Dagnino, E. (org.). Anos 90: política e sociedade no Brasil. $2^{a}$ reimp. São Paulo: Brasiliense, 2004.

DrYzeK, J. "Legitimacy and economy in deliberative democracy". Political Theory, vol. 29, n’ 5, p. 651.669, 2001.

; Niemeyer, S. “Discursive representation”. American Political Science Review, vol. 102 n 4, p.481-493, 2008.

FARIA, C. F. Sobre os determinantes das políticas participativas: a estrutura normativa e o desenho institucional dos conselhos municipais da saúde e de direitos da criança e do adolescente no Nordeste. In: AVRITZER, L.(org.). $A$ participação social no Nordeste. Belo Horizonte: UFMG, 2007.

.; SILVA, V. P.; LINS, I. L. "Conferências de políticas públicas: um sistema integrado de participação e deliberação?". Revista Brasileira de Ciência Política, Brasília, n’ 7, p. 249-284, 2012. 


\section{OPINIÃO PÚBLICA, Campinas, vol. 20, no 1, abril, 2014, p. 96-117}

FISHKIN, J. When the people speak: deliberative democracy and public consultation. Oxford: Oxford University, 2009.

Fox, J. "Civil Society and political accountability: propositions for discussion". Institutions, Accountability and Democratic Governance in Latin America. The Helen Kellogg Institute for International Studies University of Notre Dame, May 8.9, 2000. Disponível em: < http://kellogg.nd.edu/faculty/research/pdfs/Fox.pdf>. Acesso em: 20 jul. 2012

Accountability politics: power and voice in Rural Mexico. Oxford, UK: Oxford University, 2007.

Fuks, M.; PerissinotTo, R. "Recursos, decisão e poder: conselhos gestores de políticas públicas de Curitiba". Revista Brasileira de Ciências Sociais, vol. 21, n 60, p. 67. 81, fev. 2006.

FUnG, A. Receitas para esferas públicas: oito desenhos institucionais e suas consequências. In: CoelHo, V. S. P.; NOBRE, M. (orgs.). Participação e deliberação: teoria democrática e experiências institucionais no Brasil contemporâneo. São Paulo: Editora 34, 2004.

Habermas, J. Direito e democracia: entre facticidade e validade, $2^{\circ}$ vol. Tradução de Flávio Beno Siebeneichler. Rio de Janeiro: Tempo Brasileiro, 2003.

HENDRIKS, C. "Integrated Deliberation: Reconciling civil society's dual role in deliberative democracy". Political Studies, vol. 54, n³, p. 486-508, 2006.

IPEA. "Conselhos Nacionais: Perfil e atuação dos conselheiros". Relatório Final de Pesquisa, 2013. Disponível em: <http://ipea.gov.br/participacao/estudos-do-ipea/conselhosnacionais>. Acesso em: 20 jan. 2014.

KECK, M. E. PT: a lógica da diferença - o Partido dos Trabalhadores na construção da democracia brasileira. São Paulo: Ática, 1992.

Governance regimes and the politics of discursive representation. In: PIPER, N.; UHLIN, A. (Ed.). Transnational activism in Asia: problems of power and democracy. London: Routledge, 2003, p. 43-60.

KNIGHTS, M. Participation and representation before democracy: petitions and addresses in premodern Britain. In: SHAPIRO, I. et al (eds.). Political representation. Cambridge: Cambridge University, 2009.

Lavalle, A. G.; Araujo, C. "O debate sobre a representação política no Brasil: nota introdutória". Caderno CRH, Salvador, vol. 21, n 52, p. 9.12, jan./abr. 2008.

Lavalle, A. G; Houtzager, P; Castello, G. "Democracia, pluralização da representação e sociedade civil". Lua Nova, São Paulo, n 67, p. 49.103, 2006a. Disponível em: <http://www.scielo.br>. Acesso em: 15 mar. 2008.

"Representação política e organizações civis: novas instâncias de mediação e os desafios da legitimidade". Revista Brasileira de Ciências Sociais. São Paulo, vol. 21, n60, p. 44.66, 2006b. Disponível em: <http://www.scielo.br>. Acesso em: 05 jan. 2008.

LaValle, A, G.; Isunza Vera, E. Precisiones conceptuales para el debate contemporâneo sobre la innovación democrática: participación, controles sociales y representación. In: (org.). La innovación democrática en América Latina: tramas y nudos de la representación, la participación y el controle social. México: CIESAS, Universidad Veracruzana, 2010, p. 19.82. 2011.

"A trama da crítica democrática: da participação à representação e à accountability". Lua Nova, n 84, p.95.139,

LÜCHMANN, L. H. H. "Associações, participação e representação: combinações e tensões". Lua Nova, n 84, p. 141-174, 2011.

"Inclusão, accountability e representação nas instituições de controle social: dimensões da deliberação democrática". // Colóquio Internacional de Teoria Política. São Paulo, USP, mimeo, 2012.

MANIN, B. The principles of representative government. Cambridge: Cambridge University, 1997 (impressão de 2002).

Melo, C. R. Reforma política em perspectiva comparada na América do Sul. In: AvRITZer, L.; AnASTASIA, F. (org.). Reforma política no Brasil. Belo Horizonte: UFMG, 2006.

MendonçA, R.F. "Representation and deliberation in civil society". Brazilian Political Science Review, vol. 2, n², p.117.37, 2008

"Democracia discursiva: contribuições e dilemas da abordagem deliberativa do grupo australiano". $B / B, n^{\circ} 69$, p.59.77, $1^{\circ}$ sem. 2010.

Meneguello, R. Partidos e tendências de comportamento: o cenário político de 1994. In: Dagnino, E. (org.). Anos 90 : política e sociedade no Brasil. São Paulo: Brasiliense, 2004. 


\section{ALMEIDA, D. R. Pluralização da representação política e legitimidade democrática...}

MiCHELS, R. Sociologia dos partidos políticos. Tradução de Arthur Chaudon. Brasília: Universidade de Brasília, 1982.

Miguel, L. F. "Impasses da accountability. dilemas e alternativas da representação política”. Revista de Sociologia e Política, n’25, p. 25-38, 2005.

"Representação democrática: autonomia e interesse ou identidade e advocacy". Lua Nova, São Paulo, vol. 84, p.353.364, 2011.

Nicolau, J. História do voto no Brasil. Rio de Janeiro: Jorge Zahar, 2002.

PARKInSON, J. "Legitimacy problems in deliberative democracy". Political Studies, vol. 51, p. 180·196, 2003.

; MANSBRIDGE, J. Deliberative systems: deliberative democracy at the large scale. Cambridge: Cambridge University, 2012.

PINTo, C. R. J. "Espaços deliberativos e a questão da representação". Revista Brasileira de Ciências Sociais, vol. 19, n'54, p. $97 \cdot 113,2004$

PITKIN, H. F. The concept of representation. Berkeley: University of California, 1967.

REIS, F. W. "As eleições e o problema institucional". Dados - Revista Brasileira de Ciências Sociais, n 14, p. 164-210, 1977.

Rosanvallon, P. La legitimidad democrática: imparcialidad, reflexividad, proximidad. Buenos Aires: Manantial, 2009.

SAWARD, M. "The representative claim". Contemporary Political Theory, n 5, p. 297-318, 2006.

The wider canvas: representation and democracy in state and society. In: ALonso, S. et al (ed.). The future of representative democracy. Cambridge: Cambridge University, 2011, p. 74-95.

SKINNER, Q. "Hobbes on representation". European Journal of Philosophy, vol. 13, n², p. 155-184, 2005.

TATAGIBA, L. Os conselhos gestores e a democratização das políticas públicas no Brasil. In: DAGnino, E. (org.). Sociedade Civil e Espaços Públicos no Brasil. São Paulo: Paz e Terra, 2002.

URBINATI, N. Representative democracy. Chicago: University of Chicago, 2006a.

"O que torna a representação democrática?" Lua Nova, vol. 67, p. 191·228, 2006b.

Representative democracy and its critics. In: Alonso, S. et al (ed.). The future of representative democracy. Cambridge: Cambridge University, 2011

N.; WARREN, M. E. "The concept of representation in contemporary democratic theory". Annual Review of Political Science. $\mathrm{n}^{\circ} 11$, p. 387.412, 2008

VIANNA, L. W. Liberalismo e sindicato no Brasil. Belo Horizonte: UFMG, 1999.

Vieira, M. B.; Runciman, D. Representation. Cambridge: Polity, 2008.

WAMPLER, B. Transformando o Estado e a sociedade civil por meio da expansão das comunidades - política, associativa e de políticas públicas. In: Avritzer, L. (org.). A dinâmica da participação local no Brasil. São Paulo: Cortez, 2010.

Instituições participativas como "enxertos" na estrutura do Estado: a importância de contextos, atores e suas estratégias. In: PIRES, R. R. C. (Org.). A efetividade das instituições participativas no Brasil: perspectivas, abordagens e estratégias de avaliação. Brasília: IPEA, 2011

.; AvRITZer, L. "Participatory Publics: Civil Society and New Institutions in Democratic Brazil". Comparative Politics, vol. 36, n`3, p. 291-312, Apr. 2004.

Young I. M. Inclusion and democracy. Oxford: Oxford University, 2000.

Debora Rezende de Almeida·deborarezende.almeida@gmail.com

Submetido à publicação em setembro de 2012. Aprovado para publicação em setembro de 2013. 